\title{
Technological parameter optimization of multilayer enclosure structures with the multiple-criteria decision analysis
}

\author{
Elena Korol ${ }^{1 *}$, Daniil Mostovoy ${ }^{1}$ and Alexander Pleshivcev ${ }^{1}$ \\ ${ }^{1}$ Moscow State University of Civil Engineering, Yaroslavskoe shosse, 26, Moscow, 129337, Russia
}

\begin{abstract}
Nowadays modern monolithic construction is moving toward in balanced structural safety improving, energy efficiency and cost reduction with no-loss in quality characteristics. All this trends are possible due to bearing and enclosure wall construction technology optimization. Construction process efficiency is closely bounded with innovative material using both with a selection of effective work technology. To determine and justify the choice of material and construction technology researches are conducted. To select the most effective combination in the construction of enclosing building design, a multiple-criteria decision analysis of the work processability is used. The conducted numerical researches and the analysis of results have revealed that the most effective solution from the point of view of construction manufacturability of building enclosing structures and also which corresponds to the requirement of building heat protection is the using of monolith sandwich - multi-layered monolithic structure with a lowthermal conductivity concrete as a monolithic thermal insulation layer.
\end{abstract}

\section{Introduction}

In modern construction practice several types of enclosing structure walls, which show high thermal efficiency (energy efficient) characteristics, are developed: with a ventilated facade, with a "wet" facade finishing, a wall with a mineral wool insulation with a brick cladding exterior finish and a sandwich type monolithic wall with a low thermal conductivity concrete as a monolithic thermal insulation layer. Enclosure structures keep an important place in the system of building constructive safety and simultaneously create a certain level of a comfortable environment of living inside building and architectural expressiveness outside.

Special attention is attracted to the insulation characteristics of the enclosing structures in design period by the usage of high-effective thermal insulation materials, which have different physical and mechanical characteristics in comparison with the constructive materials. It forces the development of new technologies and organizational solutions for every process of its erection in building construction. The variety of constructive and technological solutions of enclosing structures poses the problem of a justified choice of its rational parameters to ensure the manufacturability of work in the construction process and

\footnotetext{
*Corresponding author: professorkorol@mail.ru
} 
the specified performance characteristics. For rational organizational and technological solution selection, a multiple-criteria decision method, which was confirmed by various studies, can be used $[2-5,7,9]$.

\section{Materials and methods}

Present enclosing structures can be compared with thermal characteristics due to the variability of the insulating material thickness; however, this affects such an important factor as the mounting processability. With the insulation thickness increasing, the labor intensity is also automatically increasing, which entails in additional financial and labor expenses. Coupled with all pros and cons, it is difficult to choose the enclosing structure, which would combine high thermal and aesthetic characteristics and have a simple installation process [6, $8,16,17]$. However, a multi-layer monolithic enclosure wall with a lightweight concrete heat-insulating layer shows to be a promising variant [1, 10-15].

The sandwich type monolithic wall combines an aesthetic, which is important for the architectural appearance of the city, and a construction process manufacturability, high fireproof characteristics with a high-energy efficiency. For analysis and subsequent determination of the most effective enclosing structure from the processability point of view, every type of enclosure wall divided on technological process steps. Technological processes and operations for each type of wall summarized in Table 1.

Table 1. Enclosure walls, construction technological processes and operations:

\begin{tabular}{|c|c|c|c|}
\hline $\begin{array}{l}\text { Curtain wall with air } \\
\text { gap (Type A) }\end{array}$ & $\begin{array}{l}\text { Wet-façade wall } \\
\text { (Type B) }\end{array}$ & $\begin{array}{l}\text { Insulated wall with } \\
\text { stone cladding (Type } \\
\text { C) }\end{array}$ & $\begin{array}{c}\text { Monolithic sandwich } \\
\text { wall with lightweight } \\
\text { concrete insulation } \\
\text { (Type D) }\end{array}$ \\
\hline 1 & 2 & 3 & 4 \\
\hline 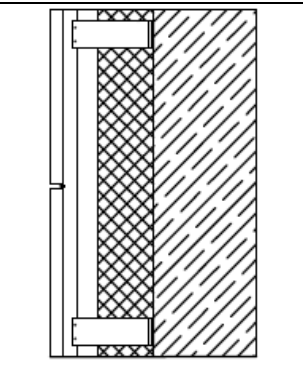 & 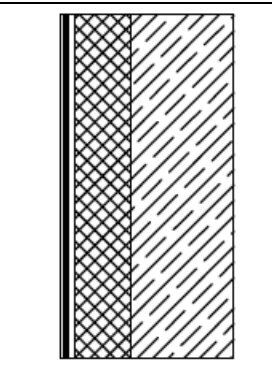 & 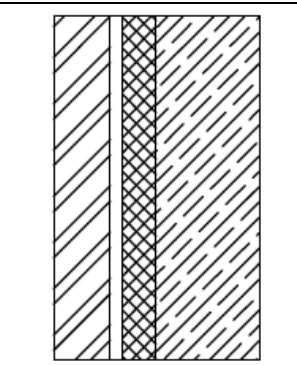 & $\therefore \therefore$ \\
\hline $\begin{array}{l}\text { 1. Rebar placement; } \\
\text { 2. Formwork } \\
\text { assembly; } \\
\text { 3. Concreting; } \\
\text { 4. Concrete curing; } \\
\text { 5. Formwork removal; } \\
\text { 6. Scaffolds assembly; } \\
\text { 7. Support-bracket } \\
\text { installation, insulation; } \\
\text { 8. Facade profile } \\
\text { subsystem installation; } \\
\text { 9. Facing installation; } \\
\text { 10. Scaffolds removal. }\end{array}$ & $\begin{array}{l}\text { 1. Rebar placement; } \\
\text { 2. Formwork } \\
\text { assembly; } \\
\text { 3. Concreting; } \\
\text { 4. Concrete curing; } \\
\text { 5. Formwork } \\
\text { removal; } \\
\text { 6. Scaffolds } \\
\text { assembly; } \\
\text { 7. Insulation; } \\
\text { 8. Plaster mesh } \\
\text { installation; } \\
\text { 9. Plastering; } \\
\text { 10. Paint works; } \\
\text { 11. Scaffolds } \\
\text { removal. }\end{array}$ & $\begin{array}{l}\text { 1. Rebar placement; } \\
\text { 2. Formwork } \\
\text { assembly; } \\
\text { 3. Concreting; } \\
\text { 4. Concrete curing; } \\
\text { 5. Formwork removal; } \\
\text { 6. Scaffolds assembly; } \\
\text { 7. Insulation; } \\
\text { 8. Stoneworks; } \\
\text { 9. Scaffolds removal. }\end{array}$ & $\begin{array}{l}\text { 1. Rebar placement; } \\
\text { 2. Permanent and } \\
\text { reusable formworks } \\
\text { assembly; } \\
\text { 3. Structural and } \\
\text { insulation concrete } \\
\text { placing; } \\
\text { 4. Concrete curing; } \\
\text { 5. Reusable } \\
\text { formwork removal. }\end{array}$ \\
\hline
\end{tabular}


Next diagrams based on the calculation results for each type of exterior wall (types A - D) of the building. All data is in Tables 2 and 3.

1) Curtain wall with air gap (Type A):

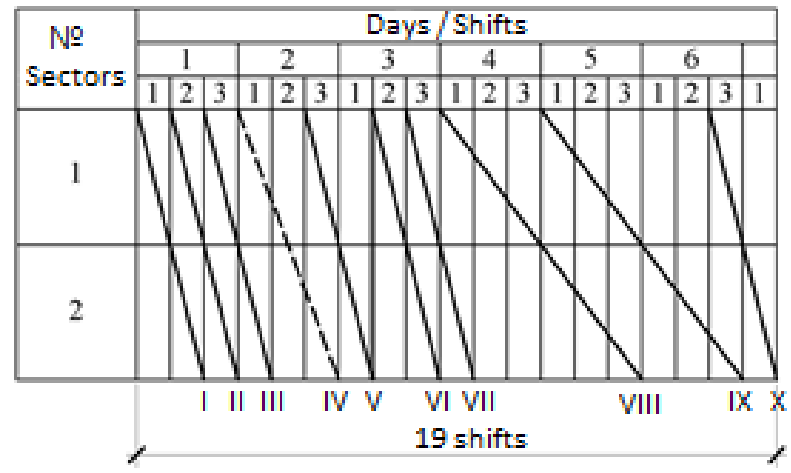

r, per. 1

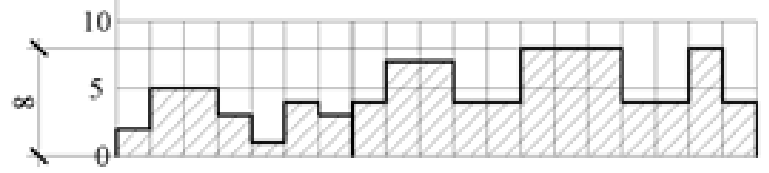

2) Wet-façade wall (Type B):

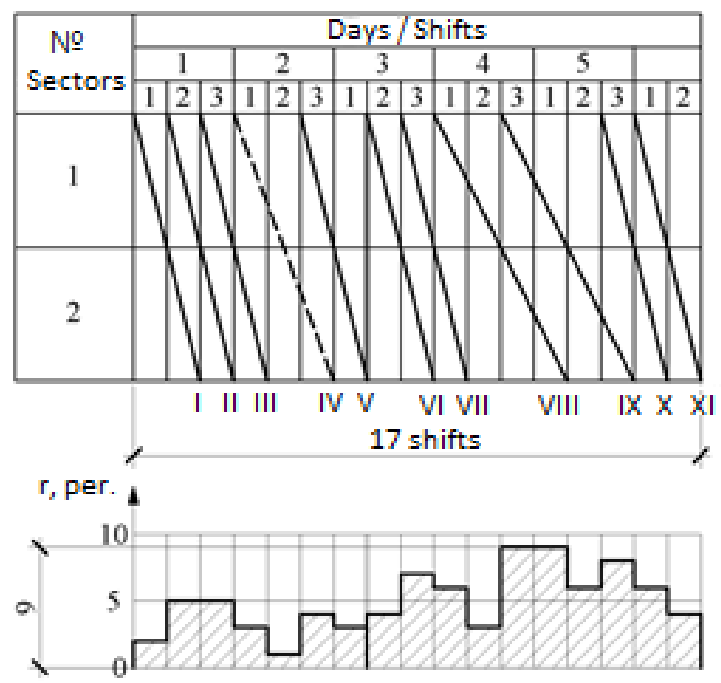

3) Insulated wall with stone cladding (Type C): 

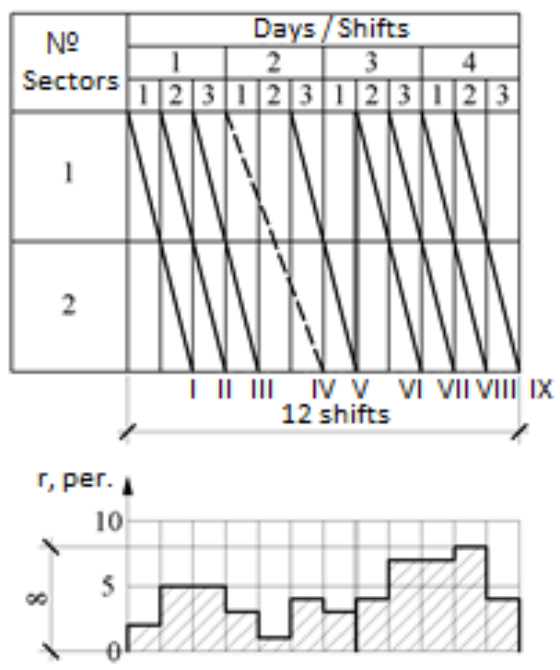

4) Monolithic sandwich wall with lightweight concrete insulation (Type D):
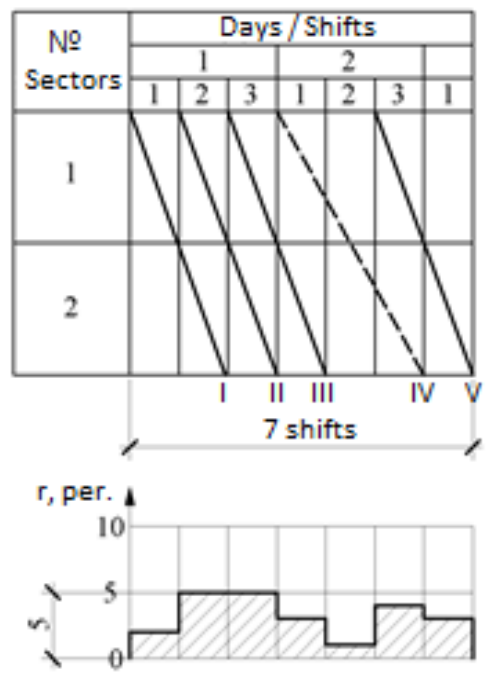

Table 2. Initial calculation data of enclosure construction work performance indexes (PI):

\begin{tabular}{|c|c|c|c|c|c|c|c|}
\hline $\begin{array}{l}\text { Wall } \\
\text { type }\end{array}$ & $\begin{array}{c}\text { Number } \\
\text { of sectors }\end{array}$ & $\begin{array}{c}\text { Total } \\
\text { work } \\
\text { duration } \\
(\mathrm{T}), \text { days }\end{array}$ & $\begin{array}{c}\text { Total } \\
\text { labor } \\
\text { resources } \\
(\mathrm{Q}), \text { staff- } \\
\text { day. }\end{array}$ & $\begin{array}{c}\text { Work } \\
\text { volume } \\
\left(\mathrm{F}_{\mathrm{pr}}\right), \mathrm{m} 2\end{array}$ & $\begin{array}{c}\text { Max. } \\
\text { duration of } \\
\text { particular } \\
\text { workflow }\end{array}$ & $\begin{array}{c}\text { Total } \\
\text { workflow } \\
\text { duration }\end{array}$ & $\begin{array}{c}\text { Max. } \\
\text { quantity } \\
\text { of } \\
\text { workers, } \\
\text { per day. }\end{array}$ \\
\hline A & 2 & 6,33 & 93 & 920,1 & 6 & 29 & 8 \\
\hline B & 2 & 5,66 & 85 & 920,1 & 4 & 27 & 9 \\
\hline C & 2 & 4 & 53 & 920,1 & 3 & 19 & 8 \\
\hline D & 2 & 2,33 & 23 & 920,1 & 3 & 11 & 5 \\
\hline
\end{tabular}


Table 3. Construction process analysis formulas and indexes of efficiency:

\begin{tabular}{|c|l|c|c|c|c|c|}
\hline \multirow{2}{*}{ No } & \multirow{2}{*}{ Index name } & \multirow{2}{*}{ Formula } & \multicolumn{4}{|c|}{$\begin{array}{c}\text { Variants of enclosure walls } \\
\text { technological processes }\end{array}$} \\
\cline { 4 - 7 } & & & $\mathrm{A}$ & $\mathrm{B}$ & $\mathrm{C}$ & $\mathrm{D}$ \\
\hline 1 & Workflow rate & $V_{p}=\frac{\mathrm{m}}{T}$ & 0,316 & 0,353 & 0,50 & 0,858 \\
\hline 2 & $\begin{array}{l}\text { Workflow } \\
\text { performance capacity }\end{array}$ & $W_{p}=\frac{F_{\mathrm{pr}}}{T}$ & 145,36 & 162,56 & 230,03 & 394,90 \\
\hline 3 & $\begin{array}{l}\text { Workflow } \\
\text { performance }\end{array}$ & $P_{p}=\frac{F_{\mathrm{pr}}}{Q}$ & 9,89 & 10,83 & 17,36 & 40,00 \\
\hline 4 & $\begin{array}{l}\text { Special complexity of } \\
\text { the work }\end{array}$ & $q_{s}=\frac{\mathrm{Q}}{F_{\mathrm{pr}}}$ & 0,101 & 0,092 & 0,058 & 0,025 \\
\hline 5 & Overall work duration & $T=\sum t_{i}$ & 6,33 & 5,66 & 4 & 2,33 \\
\hline 6 & Sector work duration & $H=\frac{\mathrm{T}}{\mathrm{m}}$ & 3,2 & 2,8 & 2 & 1.2 \\
\hline 7 & $\begin{array}{l}\text { Work combination } \\
\text { ratio }\end{array}$ & $K_{c}=\frac{\sum t_{i}-T}{\sum t_{i}-t_{\max }}$ & 0,986 & 0,928 & 0,938 & 1,084 \\
\hline 8 & $\begin{array}{l}\text { Workforce uniformity } \\
\text { ratio }\end{array}$ & $K_{r}=\frac{\mathrm{R}_{\max }}{R_{a v}}$ & 0,545 & 0,599 & 0,604 & 0,507 \\
\hline
\end{tabular}

The data obtained from the cyclograms and the Table 3 performance indexes shown in Table 4:

Table 4. Enclosure construction optimality criteria indexes:

\begin{tabular}{|c|c|c|c|c|c|c|c|c|}
\hline $\begin{array}{c}\text { Enclosure wall } \\
\text { construction method } \\
\text { type }\end{array}$ & 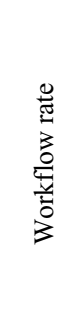 & 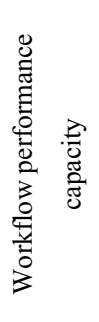 & 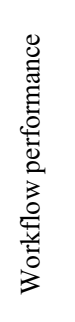 & 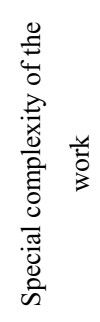 & 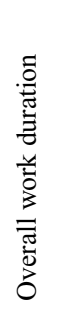 & 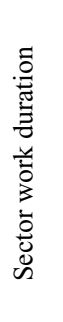 & 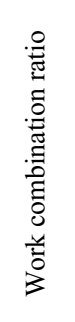 & 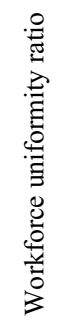 \\
\hline & $X_{1}$ & $X_{2}$ & $X_{3}$ & $X_{4}$ & $X_{5}$ & $X_{6}$ & $X_{7}$ & $X_{8}$ \\
\hline A & 0,316 & 145,36 & 9,89 & 0,101 & 6,33 & 3,2 & 0,986 & 0,545 \\
\hline B & 0,353 & 162,56 & 10,83 & 0,092 & 5,66 & 2,8 & 0,928 & 0,599 \\
\hline $\mathrm{C}$ & 0,500 & 230,03 & 17,36 & 0,058 & 4 & 2 & 0,938 & 0,604 \\
\hline $\mathrm{D}$ & 0,858 & 394,89 & 40,00 & 0,025 & 2,33 & 1,2 & 1,084 & 0,507 \\
\hline Optimality criterion & $\max$ & $\max$ & $\max$ & $\min$ & $\min$ & $\min$ & $\max$ & $\min$ \\
\hline Best value & 0,858 & 394,89 & 40,00 & 0,025 & 2,33 & 1,2 & 1,084 & 0,507 \\
\hline
\end{tabular}


The Table 4 performance indexes are collected in the matrix form. In matrix A, the column $\mathrm{X}_{\mathrm{i}}$ is the efficiency index for the row and $\mathrm{S}_{\mathrm{i}}$ - the variant of the technological solution of the enclosing structure.

\begin{tabular}{l|cccccccc}
\multicolumn{1}{c}{} & $X_{1}$ & $X_{2}$ & $X_{3}$ & $X_{4}$ & $X_{5}$ & $X_{6}$ & $X_{7}$ & $X_{8}$ \\
\cline { 2 - 8 } S1 & 0,316 & 145,36 & 9,89 & 0,101 & 6,33 & 3,2 & 0,986 & 0,545 \\
S2 & 0,353 & 162,56 & 10,83 & 0,092 & 5,66 & 2,8 & 0,928 & 0,599 \\
S3 & 0,500 & 230,03 & 17,36 & 0,058 & 4 & 2 & 0,938 & 0,604 \\
S4 & 0,858 & 394,89 & 40,00 & 0,025 & 2,33 & 1,2 & 1,084 & 0,507
\end{tabular}

To solve the matrix, the fifth line should be add as all columns have a different dimension. In the fifth line we show the best indexes in accordance to each type of efficiency criterion of every type of enclosure wall technology. The matrix A takes the following form:

\begin{tabular}{l|cccccccc}
\multicolumn{1}{c}{} & $X_{1}$ & $X_{2}$ & $X_{3}$ & $X_{4}$ & $X_{5}$ & $X_{6}$ & $X_{7}$ & $X_{8}$ \\
\cline { 2 - 8 } S1 & 0,316 & 145,36 & 9,89 & 0,101 & 6,33 & 3,2 & 0,986 & 0,545 \\
S2 & 0,353 & 162,56 & 10,83 & 0,092 & 5,66 & 2,8 & 0,928 & 0,599 \\
S3 & 0,500 & 230,03 & 17,36 & 0,058 & 4 & 2 & 0,938 & 0,604 \\
S4 & 0,858 & 394,89 & 40,00 & 0,025 & 2,33 & 1,2 & 1,084 & 0,507 \\
S5 & 0,858 & 394,89 & 40,00 & 0,025 & 2,33 & 1,2 & 1,084 & 0,507
\end{tabular}

With condition (1), we transform every element of the matrix A into matrix B:

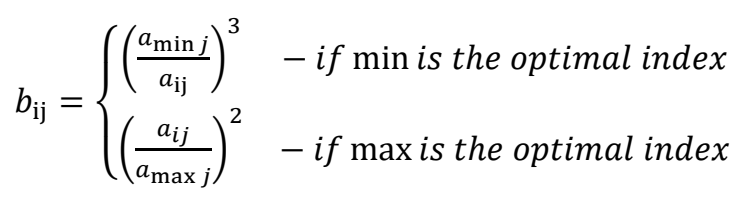

First column elements of matrix B are defined by the next way:

$$
\begin{gathered}
b_{11}=\left(\frac{a_{11}}{a_{\max 1}}\right)^{2}=\left(\frac{0,316}{0,858}\right)^{2}=0,14 ; \\
b_{21}=\left(\frac{a_{21}}{a_{\max 1}}\right)^{2}=\left(\frac{0,353}{0,858}\right)^{2}=0,17 ; \\
b_{31}=\left(\frac{a_{31}}{a_{\max 1}}\right)^{2}=\left(\frac{0,5}{0,858}\right)^{2}=0,34 ; \\
b_{41}=\left(\frac{a_{41}}{a_{\max 1}}\right)^{2}=\left(\frac{0,858}{0,858}\right)^{2}=1
\end{gathered}
$$

Second column elements of matrix B: 


$$
\begin{gathered}
b_{12}=\left(\frac{a_{12}}{a_{\max 2}}\right)^{2}=\left(\frac{145,36}{394,89}\right)^{2}=0,14 ; \\
b_{22}=\left(\frac{a_{22}}{a_{\max 2}}\right)^{2}=\left(\frac{162,56}{394,89}\right)^{2}=0,17 ; \\
b_{32}=\left(\frac{a_{32}}{a_{\max 2}}\right)^{2}=\left(\frac{230,03}{394,89}\right)^{2}=0,34 ; \\
b_{42}=\left(\frac{a_{42}}{a_{\max 2}}\right)^{2}=\left(\frac{394,89}{394,89}\right)^{2}=1
\end{gathered}
$$

Elements of columns three and seven of the matrix B are calculated by the same way as the elements of the first two columns, because it's determine performance indexes with the maximum optimum index:

$$
\begin{array}{cl}
b_{13}=\left(\frac{a_{13}}{a_{\max 3}}\right)^{2}=\left(\frac{9,89}{40}\right)^{2}=0,06 ; & b_{17}=\left(\frac{a_{17}}{a_{\max 7}}\right)^{2}=\left(\frac{0,986}{1,084}\right)^{2}=0,83 ; \\
b_{23}=\left(\frac{a_{23}}{a_{\max 3}}\right)^{2}=\left(\frac{10,83}{40}\right)^{2}=0,07 ; & b_{27}=\left(\frac{a_{27}}{a_{\max 7}}\right)^{2}=\left(\frac{0,928}{1,084}\right)^{2}=0,73 ; \\
b_{33}=\left(\frac{a_{33}}{a_{\max 3}}\right)^{2}=\left(\frac{17,36}{40}\right)^{2}=0,19 ; & b_{37}=\left(\frac{a_{37}}{a_{\max 7}}\right)^{2}=\left(\frac{0,938}{1,084}\right)^{2}=0,75 ; \\
b_{43}=\left(\frac{a_{43}}{a_{\max 3}}\right)^{2}=\left(\frac{40}{40}\right)^{2}=1 & b_{47}=\left(\frac{a_{47}}{a_{\max 7}}\right)^{2}=\left(\frac{1,084}{1,084}\right)^{2}=1
\end{array}
$$

Other elements of matrix B, which are determined by the minimal optimal performance indexes: the special complexity of the work, the duration of construction works, the sector work duration, the workforce uniformity ratio, should be calculated in the following way:

$$
\begin{array}{ll}
b_{14}=\left(\frac{a_{\min 4}}{a_{14}}\right)^{3}=\left(\frac{0,025}{0,101}\right)^{3}=0,02 ; & b_{35}=\left(\frac{a_{\min 5}}{a_{35}}\right)^{3}=\left(\frac{2,33}{4}\right)^{3}=0,02 ; \\
b_{24}=\left(\frac{a_{\min 4}}{a_{24}}\right)^{3}=\left(\frac{0,025}{0,092}\right)^{3}=0,02 ; & b_{45}=\left(\frac{a_{\min 4}}{a_{45}}\right)^{3}=\left(\frac{2,33}{2,33}\right)^{3}=1 . \\
b_{34}=\left(\frac{a_{\min 4}}{a_{34}}\right)^{3}=\left(\frac{0,025}{0,058}\right)^{3}=0,08 ; & b_{16}=\left(\frac{a_{\min 6}}{a_{16}}\right)^{3}=\left(\frac{1,2}{3,2}\right)^{3}=0,05 \\
b_{44}=\left(\frac{a_{\min 4}}{a_{44}}\right)^{3}=\left(\frac{0,025}{0,025}\right)^{3}=1 . & b_{26}=\left(\frac{a_{\min 6}}{a_{26}}\right)^{3}=\left(\frac{1,2}{2,8}\right)^{3}=0,08 \\
b_{15}=\left(\frac{a_{\min 5}}{a_{15}}\right)^{3}=\left(\frac{2,33}{6,33}\right)^{3}=0,05 ; & b_{36}=\left(\frac{a_{\min 6}}{a_{36}}\right)^{3}=\left(\frac{1,2}{2}\right)^{3}=0,22 ; \\
b_{25}=\left(\frac{a_{\min 5}}{a_{25}}\right)^{3}=\left(\frac{2,33}{5,66}\right)^{3}=0,07 ; & b_{46}=\left(\frac{a_{\min 6}}{a_{46}}\right)^{3}=\left(\frac{1,2}{1,2}\right)^{3}=1 .
\end{array}
$$




$$
\begin{aligned}
& b_{18}=\left(\frac{a_{\min 8}}{a_{18}}\right)^{3}=\left(\frac{0,507}{0,545}\right)^{3}=0,81 ; \\
& b_{28}=\left(\frac{a_{\min 8}}{a_{28}}\right)^{3}=\left(\frac{0,507}{0,599}\right)^{3}=0,61 ;
\end{aligned}
$$

$$
\begin{gathered}
b_{38}=\left(\frac{a_{\min 8}}{a_{38}}\right)^{3}=\left(\frac{0,507}{0,604}\right)^{3}=0,59 \\
b_{48}=\left(\frac{a_{\min 8}}{a_{48}}\right)^{3}=\left(\frac{0,507}{0,507}\right)^{3}=1 .
\end{gathered}
$$

As in the last line of the matrix, all elements are equal to 1, this line will not influence to the option of the optimal final solution, therefore transformed matrix B has the following form:

\begin{tabular}{lrrrrrrrc}
\multicolumn{1}{c}{} & $X_{1}$ & $X_{2}$ & $X_{3}$ & $X_{4}$ & $X_{5}$ & $X_{6}$ & $X_{7}$ & $X_{8}$ \\
\cline { 2 - 9 }$S 1$ & 0,14 & 0,14 & 0,06 & 0,02 & 0,05 & 0,05 & 0,83 & 0,81 \\
$S 2$ & 0,17 & 0,17 & 0,07 & 0,02 & 0,07 & 0,08 & 0,73 & 0,61 \\
$S 3$ & 0,34 & 0,34 & 0,19 & 0,08 & 0,20 & 0,22 & 0,75 & 0,59 \\
$S 4$ & 1,00 & 1,00 & 1,00 & 1,00 & 1,00 & 1,00 & 1,00 & 1,00 \\
$S 5$ & 1,00 & 1,00 & 1,00 & 1,00 & 1,00 & 1,00 & 1,00 & 1,00
\end{tabular}

The matrix $\mathrm{B}$ is calculated by the method of solving conflict situations with nondefiniteness. The optimal selection can be determined with the Wald's and Savage's evaluation criteria and the Hurwitz's method.

The optimal enclosure construction technology according to the Wald's minimax method is determined by the following formula (2):

$$
V_{o p t}=\max _{i} \quad\left[\min b_{i j}\right]
$$

The minimum gain is calculated in each row of matrix $\mathrm{B}$. The maximum result means the best choice:

$$
\begin{gathered}
\min b_{1 j}=0,02(j=1,2 \ldots 8) ; \\
\min b_{2 j}=0,02(j=1,2 \ldots 8) ; \\
\min b_{3 j}=0,08(j=1,2 \ldots 8) ; \\
\min b_{4 j}=1(j=1,2 \ldots 8) . \\
V_{\text {opt }}=\max \quad[0,02 ; 0,02 ; 0,08 ; 1]=1=b_{44} .
\end{gathered}
$$

The optimal solution choice by the Savage's method of minimax risk is calculated with the matrix B performance values, which are expressed in the risk values with formula (3):

$$
r_{i j}=\max _{i} b_{j}-b_{i j}
$$

After transformation, we have the matrix B. These matrix's elements show the risk values: 


\begin{tabular}{c|cccccccc}
\multicolumn{1}{c}{} & $X_{1}$ & $X_{2}$ & $X_{3}$ & $X_{4}$ & $X_{5}$ & $X_{6}$ & $X_{7}$ & $X_{8}$ \\
\cline { 2 - 9 } S1 & 0,86 & 0,86 & 0,94 & 0,98 & 0,95 & 0,95 & 0,17 & 0,19 \\
$S 2$ & 0,83 & 0,83 & 0,93 & 0,98 & 0,93 & 0,92 & 0,27 & 0,39 \\
$S 3$ & 0,66 & 0,66 & 0,81 & 0,92 & 0,80 & 0,78 & 0,25 & 0,41 \\
S4 & 0 & 0 & 0 & 0 & 0 & 0 & 0 & 0
\end{tabular}

The optimal technological solution of enclosure walls can be determined with the Savage's minimax risk method (the method of extreme pessimism) with formula (4):

$$
\begin{aligned}
& V_{\text {opt }}=\min _{i}\left[\begin{array}{c}
\left.\max r_{i j}\right] \\
j
\end{array}\right. \\
& \max r_{1 j}=0,98(j=1,2 \ldots 8) \text {; } \\
& \max r_{2 j}=0,98(j=1,2 \ldots 8) \text {; } \\
& \max r_{3 j}=0,92(j=1,2 \ldots 8) \text {; } \\
& \max r_{4 j}=0(j=1,2 \ldots 8) . \\
& V_{\text {opt }}=\min _{i} \quad[0,98 ; 0,98 ; 0,92 ; 0]=0
\end{aligned}
$$

The Hurwitz's pessimism-optimism method allows you to determine the optimal solution in the range from extreme pessimism to extreme optimism with an average multiplier e $(0.4$ $\leq \mathrm{e} \leq 0.6)$, with formula (5):

$$
\begin{gathered}
V_{o p t}=\max _{i}\left[e * \min b_{i j}+(1-e) \max b_{i j}\right] \\
e * \min b_{1 j}+(1-e) \max b_{1 j}=0,075(j=1,2 \ldots 8) \\
e * \min b_{2 j}+(1-e) \max b_{2 j}=0,094(j=1,2 \ldots 8) \\
e * \min b_{3 j}+(1-e) \max b_{3 j}=0,21(j=1,2 \ldots 8) \\
e * \min b_{4 j}+(1-e) \max b_{4 j}=1(j=1,2 \ldots 8) \\
V_{o p t}=\max \quad[0,075 ; 0,094 ; 0,21 ; 1]=1 .
\end{gathered}
$$

\section{Results}

The final step is to find the optimal solution, which will fit for the method's condition:

$$
V_{o p t}=\max _{i} \quad[0,02 ; 0,02 ; 0,08 ; 1]=1=b_{44} .
$$

According to the Wald's minimax method, the optimum result is equal to 1 . It belongs to the element of the fourth row of the fourth column of the matrix B (the efficiency index is the specific labor intensity of the work); therefore, the optimal variant by the Wald's method is the fourth option - multi-layer enclosure wall with monolithic lightweight concrete 
insulation layer (type D).

$$
V_{\text {opt }}=\min _{i} \quad[0,98 ; 0,98 ; 0,92 ; 0]=0=r_{44} .
$$

The optimal variant of the organizational and technological solution according to Savage's minimax risk method (the extreme pessimism method), is the fourth variant (enclosure structure type D).

$$
V_{\text {opt }}=\max _{i} \quad[0,075 ; 0,094 ; 0,21 ; 1]=1=b_{44} .
$$

The optimal solution by the Hurwitz's pessimism-optimism method is determined by the value $b_{44}=1,-$ it means that the best variant of the organizational and technological solution for vertical enclosure structures is type D - sandwich wall with lightweight low-conductive concrete insulation.

\section{Discussion}

Multiple-criteria decision analysis allows to determine the most efficient method of construction works according to the basis of optimality criteria for all listed types of enclosure structures. As a result of mathematical analysis a multi-layered enclosing structure with a non-removable formwork and a lightweight concrete as insulation layer is the technology that reduces both the labor and time resources, which subsequently results in financial profit.

\section{Conclusion}

The multicriteria analysis of efficiency and optimality parameters of the enclosure structures showed that a multi-layer monolithic structure with a low-heat-conductive lightweight concrete insulating layer is the efficient and effective enclosure structure in comparison with other types. Planning a multi-layer enclosing structure at predesign phase will save design time, workforce resources at site, and estimated construction time reduction in conjunction with other factors generally will increase the economic profitability of construction.

\section{References}

1. E.A. Korol', E.M. Pugach, A.E. Nikolaev Arhitektura i stroitel'stvo 5, 415 (2009)

2. E.A. Korol', S.V. Komissarov, P.B. Kagan, S.G. Arutyunov Promyshlennoe i grazhdanskoe stroitel'stvo 3, 43 (2011)

3. P.P. Olejnik, V.I. Brodskij Promyshlennoe i grazhdanskoe stroitel'stvo 12, 30 (2012)

4. E.K. Zavadskas Sistemotekhnicheskaya ocenka tekhnologicheskih reshenij stroitel'nogo proizvodstva (Strojizdat, 1991)

5. M. Keshavarz Ghorabaee, M. Amiri,E.K. Zavadskas,Z. Turskis, J.A. Antucheviciene Computers and Industrial Engineering 112, 156 (2017)

6. K.P. Grabovyj, O.A. Korol' Estestvennye i tekhnicheskie nauki 11-12, 399 (2014)

7. A. Krylovas, E.K. Zavadskas, N. Kosareva, S. Dadelo International Journal of Information Technology \& Decision Making 13, 1119 (2014) 
8. O.A. Korol' Nauchnoe obozrenie 12, 327 (2015)

9. E.A. Korol', A.A. Pleshivcev Promyshlennoe i grazhdanskoe stroitel'stvo 5, 57 (2017)

10. E.A. Korol', Y.A. Kharkin Stroitel'stvo i rekonstrukciya 6, 3 (2013)

11. E.A. Korol', Y.A. Kharkin Zhilishchnoe stroitel'stvo 7, 32 (2014)

12. E.A. Korol, Y.A. Kharkin Sbornik dokladov XX Rossiysko-Polsko-Slovatskogo seminara «Teoreticheskie osnovy stroitelstva 401 (2011)

13. Y.A. Kharkin, E. Korol, A. Davidyuk Procedia Engineering. 117, 172 (2015)

14. E.A. Korol, A.A. Davidyuk, A.A. Zolotarev Izvestiya Vysshikh Uchebnykh Zavedenii, Seriya Teknologiya Tekstil'noi Promyshlennosti 5, 239 (2015)

15. E.A. Korol, Y.O. Kustikova E3S Web of Conferences 33, 01043 (2018)

16. E.A. Korol, E., O.A. Korol E3S Web of Conferences 33, 02076 (2018)

17. P.P. Olejnik, B.V. Zhadanovskij, M.F. Kuzhin, S.A. Sinenko, V.I. Brodskij, L.A.

Pakhomova Vozvedeniye monolitnykh konstruktsiy zdaniy i sooruzheniy (MISI-MGSU, 2018) 